\title{
Pengaruh Model Pembelajaran Inkuiri Terbimbing dengan Metode Eksperimen terhadap Hasil Belajar Fisika Siswa Kelas XI IPA SMAN 2 Mataram Tahun Pelajaran 2016/2017
}

\author{
Roni Wahyuni ${ }^{1}$, Hikmawati ${ }^{2}$, Muhammad Taufik ${ }^{3}$ \\ Program Studi Pendidikan Fisika \\ Universitas Mataram \\ Mataram, Indonesia \\ Email: roniwahyuni01@gmail.com
}

\begin{abstract}
This study is aimed todetermine the effect of guided-inqury learning model combined with the experimental method on physics learning outcomes grade XI IPA in SMAN 2 Mataram of academic year 2016/2017. This is quasi-experimental research with pretest and posttest control group design. The population is all students grade XI IPA in SMAN 2 Mataram and the sample is student class XI IPA-7 as the experimental group and class XI IPA-9 as the control one which is selected by purposive sampling. The data of physics outcomes learning is collected by using multiple-choice test. Average value obtained in experimental class is 77.00, while in control is 65.65. The highest $N$-gain value is in sub material elasticity properties of material, it is $51 \%$ in control and $88 \%$ in experimental. Statistical used is t-test polled variance at significant level of $5 \%$ and the result obtained $t_{\text {count }}$ is 6,27 . This value is greater than $t_{\text {table }}\left(t_{\text {table }}=1.993\right)$. It means that there is an influence of guided-inquiry learning model combined with the experimental method on physics learning outcomes grade XI IPA in SMAN 2 Mataram.
\end{abstract}

Keywords: Guided-inquiry learning, experimental methods, learning outcome

\section{Pendahuluan}

Fisika merupakan salah satu cabang ilmu IPA (sains) memiliki hakekat yakni fisika sebagai produk (a body of knowledge), fisika sebagai sikap (a way of thinking) dan fisika sebagai proses [1]. Ilmu IPA diharapkan dapat menjadi wahana bagi peserta didik untuk mempelajari diri sendiri dan alam sekitar serta menerapkannya dalam kehidupan sehari-hari. Untuk itu, pembelajaran IPA hendaknya menggunakan model pembelajaran yang dapat membawa siswa kedalam situasi yang nyata, dimana siswa dapat melihat dan membuktikan sendiri pengetahuan berdasarkan fakta yang ada serta memperoleh pengalaman konkret [2].

Peristiwa belajar mengajar banyak berakar pada berbagai pandangan dan konsep. Oleh karena itu, perwujudan proses belajar mengajar dapat terjadi dalam berbagai model [3]. Untuk itu, dalam proses belajar mengajar diperlukan suatu model pembelajaran yang termasuk kedalam rumpun modelmodel pemrosesan informasi yang menekankan bgaimana seseorang berfikir dan dampaknya terhadap cara-cara mengolah informasi [4].

Berdasarkan hasil observasi yang peneliti lakukan di SMAN 2 Mataram melalui wawancara dengan salah seorang guru dan beberapa siswa, bahwa metode yang digunakan dalam pembelajaran fisika yaitu metode ceramah, metode diskusi, dan metode eksperimen. Namun model pembelajaran yang lebih sering digunakan adalah model pembelajaran langsung dengan metode ceramah, dimana di dalam proses pembelajaran masih didominasi oleh peran aktif guru dan siswa masih kurang aktif, dengan kata lain pembelajaran masih bersifat teacher center bukan student center. Hal ini yang memberikan dampak pada hasil belajar fisika siswa yang masih rendah.

Menyikapi permasalahan yang ada tersebut, maka diperlukan suatu model pembelajaran yang berorientasi pada siswa sehingga pembelajaran lebih berpusat pada siswa (student center) bukan hanya berpusat pada guru (teacher center). Model pembelajaran yang dimaksud adalah model pembelajaran inkuiri terbimbing dengan metode eksperimen. Model ini tentunya diharapkan dapat memberikan perubahan pada hasil belajar fisika menjadi lebih baik dari sebelumnya. Menurut Gulo dalam Putra [5], strategi inkuiri berarti suatu kegiatan belajar yang melibatkan secara maksimal seluruh kemampuan siswa untuk mencari dan menyelidiki secara sistematis, kritis, logis dan analitis sehingga dapat merumuskan sendiri penemuannya dengan penuh percaya diri.

Pembelajaran inkuiri memiliki beberapa tahapan yakni menetapkan masalah, merumuskan hiposesis, melakukan percobaan/eksperimen, mengolah dan menganalisis data, menguji hipotesis hingga membuat kesimpulan. Model pembelajaran ini akan menantang siswa untuk senantiasa aktif selama proses pembelajaran sekaligus mendorong siswa untuk mengoptimalkan keterampilan dan kemampuannya [6]. Peran siswa dalam model pembelajaran inkuiri ini yaitu mencari dan 
menemukan sendiri materi pelajaran, sedangkan guru berperan sebagai fasilitator dan pembimbing siswa untuk belajar. Pada model pembelajaran inkuiri terbimbing, guru memberikan bimbingan dan petunjuk bagi siswa selama kegiatan pembelajaran [7].

Beberapa penelitian sebelumnya menunjukkan sejumlah pengaruh penggunaan model pembelajaran inkuiri terbimbing dalam pembelajaran di kelas. Yulian, dkk, menemukan bahwa model pembelajaran inkuiri terbimbing dengan metode eksperimen mengalami peningkatan hasil pada aktivitas siswa dan hasil belajarnya. hasil belajar aspek kognitif siswa yang diperoleh siswa yaitu 68,97 dan rata-rata nilai aktivitas belajar yang diperoleh siswa sebesar 73, 90 pada kelas kontrol, sedangkan pada kelas eksperimen diperoleh hasil belajar aspek kognitif sebesar 77,32 dan rata-rata nilai aktivitas belajar yang diperoleh siswa sebesar 83,51 [8].

Wijayanti, dkk, menemukan bahwa hasil belajar kognitif siswa mengalami peningkatan nilai rata-rata serta terpenuhinya ketuntasan belajar siswa setelah diterapkannya model pembelajaran inkuiri terbimbing pada pokok bahasan cahaya dikelas eksperimen. Hasil yang diperoleh yaitu pada kelas ekpserimen nilai rata-rata sebelumnya 51,84 menjadi 75,85 dean ketuntasan belajar siswa juga meningkat dari $28,57 \%$ meningkat menjadi $85,71 \%$ [9].

Isa, dkk, dengan hasil bahwa model inkuiri terbimbing dapat meningkatkan minat dan hasil belajar siswa di SMAN 14 Semarang yakni siswa yang mencapai ketuntasan meningkat dari 13 siswa menjadi 38 siswa dan tanggapan siswa sebelum tindakan sebesar $72,90 \%$ dan setelah tindakan meningkat menjadi $76,81 \%$ [10].

\section{Tinjauan Pustaka}

\section{A. Model Pembelajaran Inkuiri Terbimbing}

Model pembelajaran adalah kerangka konseptual yang melukiskan prosedur sistematis dalam mengorganisasikan pengalaman belajar untuk mencapai tujuan pembelajaran [11].. Inkuiri yang dalam bahasa inggris inquiry, berarti pertanyaan atau pemeriksaan, penyelidikan. Inkuiri sebagai suatu proses umum yang dilakukan manusia untuk mencari atau memahami informasi [4]. Schmid dalam Putramengemukan bahwa inkuiri adalah suatu proses untuk memperoleh dan mendapatkan informasi dengan melakukan observasi atau eksperimen guna mencari jawaban maupun memecahkan masalah terhadap pertanyaan atau rumusan masalah dengan menggunakan kemampuan berfikir kritis dan logis [5]. Sasaran utama kegiatan pembelajaran inkuiri adalah (1) keterlibatan siswa secara maksimal dalam proses kegiatan belajar; (2) keterarahan kegiatan secara logis dan sistematis pada tujuan pembelajaran; dan (3) mengembangkan sikap percaya pada diri siswa tentang apa yang ditemukan dalam proses inkuiri [4].

Model Pembelajaran Inkuiri (selanjutnya disebut MPI) adalah suatu model pembelajaran yang dikembangkan agar siswa menemukan dan menggunakan berbagai sumber informasi dan ide-ide untuk meningkatkan pemahaman tentang masalah, topik, atau isu tertentu. Penggunaan model ini menuntut siswa untuk mampu untuk tidak hanya sekedar menjawab pertanyaan atau mendapatkana jawaban yang benar. Model ini menuntut siswa untuk melakukan serangkaian investigasi, eksplorasi, pencarian, eksperimen, penelusuran, dan penelitian [6].

Pada penelitian ini, tahapan pembelajaran yang digunakan mengadaptasi dari tahapan pembelajaran inkuiri yang dikemukakan oleh Eggen \& Kauchak (1996) dalam Trianto [4]. Tahapan model pembelajaran inkuitri terbimbing dapat dilihat pada Tabel 1. berikut.

Tabel.1. Sintaks Model Pembelajaran Inkuiri Terbimbing

\begin{tabular}{|c|c|c|}
\hline \multicolumn{2}{|r|}{ Fase } & Perilaku Guru \\
\hline 1. & $\begin{array}{l}\text { Menyajikan } \\
\text { pertanyaan atau } \\
\text { masalah }\end{array}$ & $\begin{array}{llr}\text { - } & \text { Guru membimbing siswa } \\
\text { mengidentifikasi masalah dan } \\
\text { masalah dituliskan di papan tulis. } \\
\text { - } & \text { Guru mebagi siswa dalam kelompok }\end{array}$ \\
\hline 2. & $\begin{array}{l}\text { Membuat } \\
\text { hipotesis }\end{array}$ & $\begin{array}{l}\text { - Guru memberikan kesempatan pada } \\
\text { siswa untuk curah pendapat dalam } \\
\text { membentuk hipotesis serta } \\
\text { memberikan bimbingan. } \\
\text { - Guru membimbing siswa dalam } \\
\text { menentukan hipotesis yang relevan } \\
\text { dengan permasalahan dan } \\
\text { memprioritaskan hipotesis mana } \\
\text { yang menjadi hipotesis pendidikan }\end{array}$ \\
\hline 3. & $\begin{array}{l}\text { Merancang } \\
\text { percobaan }\end{array}$ & $\begin{array}{l}\text { - Guru memberikan kesempatan pada } \\
\text { siswa untuk menentukan langkah- } \\
\text { langkah yang sesuai dengan } \\
\text { hipotesis yang akan dilakukan. } \\
\text { - Guru membimbing siswa } \\
\text { mengurutkan langkah-langkah } \\
\text { percobaan. }\end{array}$ \\
\hline 4. & $\begin{array}{l}\text { Melakukan } \\
\text { percobaan untuk } \\
\text { memperoleh } \\
\text { informasi }\end{array}$ & $\begin{array}{l}\text { - Guru membimbing } \\
\text { mendapatkan informasi melalui } \\
\text { percobaan }\end{array}$ \\
\hline 5. & $\begin{array}{l}\text { Mengumpulkan } \\
\text { dan menganaisis } \\
\text { data }\end{array}$ & $\begin{array}{l}\text { - Guru membimbing siswa untuk } \\
\text { mengumpulkan dan menganalisis } \\
\text { data. }\end{array}$ \\
\hline & & $\begin{array}{l}\text { - Guru memberi kesempatan pada } \\
\text { tiap kelompok untuk menyampaikan } \\
\text { hasil pengolahan data yang } \\
\text { terkumpul }\end{array}$ \\
\hline 6. & $\begin{array}{l}\text { Membuat } \\
\text { kesimpulan }\end{array}$ & $\begin{array}{l}\text { - Guru membimbing siswa dalam } \\
\text { membuat kesimpulan }\end{array}$ \\
\hline
\end{tabular}

(Diadaptasi dari Trianto, 2013) 


\section{B. Metode Eksperimen}

Metode eksperimen merupakan suatu cara penyajian pelajaran dimana siswa melakukan percobaan untuk membuktikan suatu pertanyaan atau hipotesis yang dipelajari.Metode eksperimen (percobaan) adalah cara penyajian pelajaran, dimana siswa melakukan percobaan dengan mengalami dan membuktikan sendiri sesuatu yang dipelajari. Dengan demikian, siswa dituntut untuk mengalami sendiri, mencari kebenaran,mencoba mencari tahu suatu hukum atau dalil, dan menarik kesimpulan atas proses yang dialaminya itu [12].

Lebih lanjut lagi diungkapkan oleh Sagala [13], bahwa metode eksperimen adalah cara penyajian bahan pelajaran dimana siswa melakukan percobaan dengan mengalami untuk membuktikan sendiri suatu pertanyaan atau hipotesis yang dipelajari. Dalam proses mengajar mengajar dengan metode eksperimen ini siswa diberi kesempatan untuk mengalami sendiri atau melakukan sendiri, mengikuti proses, mengamati suatu objek, menganalisis, membuktikan dan menarik kesimpulan sendiri tentang suatu objek, keadaan atau proses sesuatu.

\section{Hasil Belajar Fisika}

Proses belajar mengajar adalah proses bertujuan sesuai rumusan tingkah laku yang diharapkan harus dimiliki siswa setelah menyelesaikan pengalaman belajarnya. Hasil yang diperoleh dari penilaian diperoleh dari hasil belajar. Oleh sebab itu, tindakan atau kegiatan tersebut dinamakan hasil belajar [14]. Hasil belajar diartikan sebagai proses perubahan tingkah laku pada diri individu berkat adanya interaksi antara individu dan individu dengan lingkungannya. Seseorang setelah mengalami proses belajar akan mengalami perubahan tingkah laku, baik aspek pengetahuannya (kognitif), keterampilannya maupun aspek sikapnya. Dalam hal ini, peran/ tugas guru amatlah penting. Oleh karenanya, tugas guru sebagai profesi meliputi mendidik, mengajar dan melatih [3].Bloom membagi hasil belajar ranah kognitif kedalam enam aspek, yakni pengetahuan atau ingatan $(\mathrm{C} 1)$, pemahaman (C2), aplikasi (C3), analisis (C4), sintesis (C5) dan evaluasi (C6). Kedua aspek pertama disebut kognitif tingkat rendah dan keempat aspek berikutnya termasuk kognitif tingkat tinggi [15].

\section{MetodePenelitian}

Penelitian termasuk penelitian eksperimen semu dimana pada penelitian eskperimen semu peneliti tidak memiliki keleluasaan memanipulasi subjek [16]. Desain penelitian menggunakan pre-test and post-test control group design, dalam pelaksanaannya diawali dengan pemberian tes awal kepada kedua kelompok sampel, kemudian kedua kelompok mendapatkan perlakuan yang berbeda yaitu kelompok eksperimen diberikan perlakuan berupa penerapan pembelajaran model pembelajaran inkuiri terbimbing dengan metode eksperimensedangkan bagi kelompok kontrol diberikan perlakuan dengan menerapkan pembelajaran konvensional di sekolah berupa pengajaran langsung, dan diakhiri dengan dilakukan tes akhir pada kedua sampel.

Teknik pengambilan sampel pada penelitian ini menggunakan purposive samplingdengan sampel seluruh kelas XI IPA SMAN 2 MATARAM.Analisis data hasil belajar fisika siswa pada tes awal dan akhir diawali dengan menguji prasyarat analisis yaituuji homogenitas menggunakan uji varians atau uji-F dan uji normalitas menggunakan rumus uji chi kuadrat []. Kemudian, analisis data hasil tes akhir uji hipotesis dalam penelitian ini menggunakan uji $t$-test polled varians[17]. Peningkatan hasil belajar siswa pada setiap sub materielastisitas dan hukum Hooke dianalisis menggunakan uji n-gain. Uji N-gain dilakukan dengan menggunakan rumus [18]:

$$
g=\frac{S_{\text {post }}-S_{\text {pre }}}{S_{\text {max }}-S_{\text {pre }}} \times 100 \%
$$

Tabel 2. Kriteria Skor N-gain

\begin{tabular}{lc}
\hline \multicolumn{1}{c}{ Nilai $\boldsymbol{N \text { -gain }}$} & Kategori \\
\hline $70<N$-gain & Tinggi \\
$30 \leq N$-gain $\leq 70$ & Sedang \\
$N$-gain $<30$ & Rendah \\
\hline
\end{tabular}

\section{HASIL DAN PEMbahasan}

Dalam penelitian ini, hasil belajar yang diukur adalah kemampuan kognitif siswa pada materi elastisitas dan hukum Hooke. Kemampuan penguasaan konsep siswa dapat diketahui melalui data hasil tes awal dan tes akhir yang disajikan dalam Tabel 3.

Tabel 3. Data Hasil Tes Awal dan Tes Akhir Hasil Belajar Fisika Siswa

\begin{tabular}{ccccccc}
\hline \multirow{2}{*}{ Kelas } & Tes & $\begin{array}{c}\text { Jumlah } \\
\text { Siswa }\end{array}$ & $\begin{array}{c}\text { Nilai } \\
\text { Terendah }\end{array}$ & $\begin{array}{c}\text { Nilai } \\
\text { Tertinggi }\end{array}$ & Rata-Rata & Varians \\
\hline \multirow{2}{*}{ Eksperimen } & Awal & 39 & 30.00 & 60.00 & 43.67 & 84,14 \\
& Akhir & 39 & 60.00 & 90.00 & 77.00 & 47,37 \\
\multirow{3}{*}{ Kontrol } & Awal & 37 & 30.00 & 63.33 & 43.76 & 57,93 \\
& Akhir & 37 & 50.00 & 80.00 & 65.65 & 78,68 \\
\hline
\end{tabular}


Pada Tabel 3 terlihat bahwa hasil belajar siswa pada saat tes awal dan tes akhir siswa berbeda. Peningkatan hasil tes akhir terjadi pada kelas kontrol dan kelas eskperimen, akan tetapi peningkatan lebih besar pada kelas eksperimen yang menggunakan model pembelajaran inkuiri terbimbing dengan metode eksperimen. Hasil analisis uji hipotesis pada taraf signifikansi $5 \%$ diperoleh $\mathrm{t}_{\text {hitung }}=6,27$ lebih besar dari $\mathrm{t}_{\text {tabel }}=$ 1.993. Hal ini menunjukkan bahwa hasil belajar fisika siswa yang menggunakan model pembelajaran inkuiri terbimbing degan metode eksperimen memberikan pengaruh lebih baik dibandingkan dengan model pembelajaran konvensional pada materi elastisitas dan hukum Hooke.

Berdasarkan hasil pengamatan peneliti selama proses pembelajaran berlangsung, terlihat bahwa model pembelajaran inkuiri terbimbing dengan metode eksperimen yang diberikan pada kelas ekperimen membuat siswa lebih aktif dalam belajar dan meningkatkan hasil belajar fisika siswa. Penggunaan metode eksperimen pada model pembelajaran inkuiri ini sangat mendukung siswa dalam menemukan konsep-konsep pada materi elastisitas dan hukum Hooke.Hasil ini sesuai dengan hasil penelitian sebelumnya yang menunjukkan bahwa hasil belajar kognitif siswa mengalami peningkatan rata-rata serta terpenuhinya ketuntasan belajar siswa setelah diterapkannya model pembelajaran inkuiri terbimbing [9]. Penelitian lain juga menunjukkan bahwa penggunaan model pembelajaran inkuiri terbimbing dengan metode eksperimen dapat meningkatkan aktivitas dan hasil belajar fisika siswa [8].

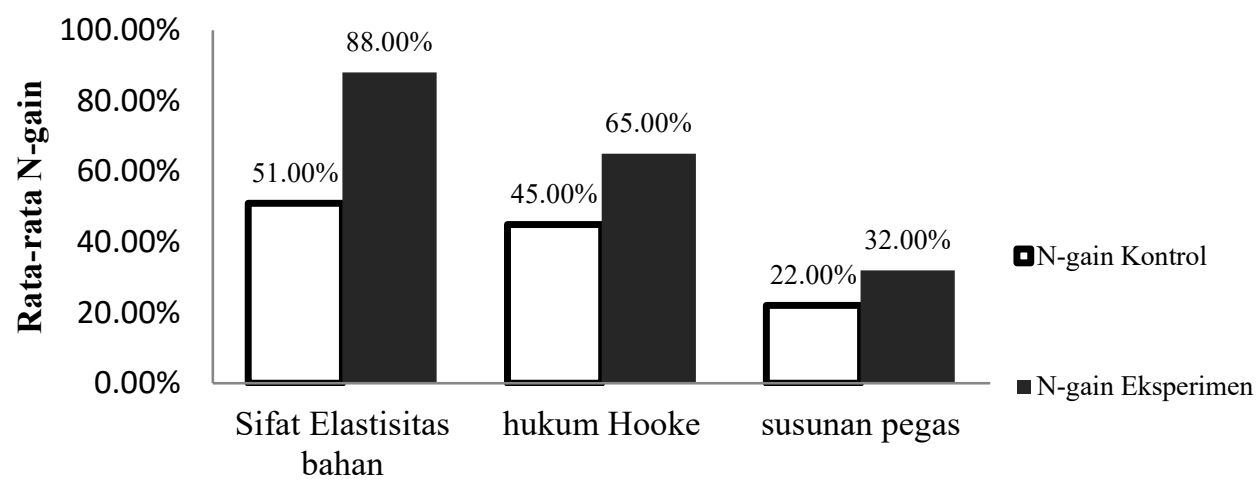

Gambar 1. Perbandingan Skor N-gainSetiap Sub Materi pada Kedua Kelas

Materi elastisitas dan hukum Hooke dalam penelitian ini dibatasi pada 3 sub materi, yaitu sifat elastisitas bahan, hukum Hooke dan susunan pegas. Perbandingan persentase peningkatan penguasaan konsep untuk setiap sub materi elastisitas dan hukum Hooke pada kelas eksperimen dan kelas kontrol ditampilkan pada Gambar 1 dibawah.

Pada Gambar 1 dapat diketahui bahwa terdapat perbedaan peningkatan penguasaan konsep setiap sub materi antara kelas eksperimen dan kelas kontrol. Secara keseluruhan peningkatan sub materi kelas eksperimen lebih tinggi dibandingkan kelas kontrol. Pada kelas eksperimen, N-gain tertinggi berada pada sub materi sifat elastisitas bahan yakni sebesar $88 \%$. Hampir seluruh soal mengenai sifat elastisitas bahan dapat dijawab siswa dengan benar pada kelas eskperimen. Hal ini dikarenakan soal-soal tersebut termasuk dalam kategori mudah. Persentase siswa yang menjawab dengan benar sebanyak 59\% pada tes awal dan sebanyak $95 \%$ pada tes akhir. Banyaknya persentase siswa yang dapat menjawab soal berkaitan dengan sifat elastisitas bahan ini dikarenakan soal termasuk dalam kategori mudah

hingga sedang meskipun terdapat 1 soal yang termasuk dalam kategori sukar.

Baik kelas kontrol maupun kelas eksperimen, grafik paling tinggi pada sub materi sifat elastisitas bahan dan paling rendah pada sub materi susunan pegas serta nilai $\mathrm{N}$-gain kelas eksperimen lebih besar dibandingkan kelas kontrol. Nilai N-gain sub materi hukum Hooke yaitu $64,85 \%$ pada kelas eksperimen dan $43,98 \%$ pada kelas kontrol. Jika dibandingkan dengan Ngain kelas eksperimen, nilai $\mathrm{N}$-gain kelas kontrol lebih kecil. Hal ini menunjukkan penggunaan 
model pembelajaran inkuiri terbimbing dengan metode eksperimen ini dapat memberikan hasil yang lebih baik dibandingkan kelas yang menggunakan model pembelajaran konvensional. Hal ini sudah dibuktikan oleh penelitian yang dilakukan oleh Justitia dan Supardi [19], dengan hasil bahwa model pembelajaran inkuiri dapat meningkatkan hasil belajar siswa pada materi elastisitas dan hukum Hooke. Nilai rata-rata yang diperoleh pada kelas eksperimen yang menggunakan model pembelajaran inkuiri sebesar 3,09 sedangkan pada kelas kontrol sebesar 3,03. Penelitian serupa juga dilakukan oleh Sihombing [20], dengan hasil bahwapenerapan pembelajaran dengan pendekatan inkuiri terbimbing melalui metode eksperimen pada materi elastisitas, hasil belajar peserta didik lebih baik dibandingkan dengan metode pembelajaran langsung di SMA Negeri 3 Jayapura.

Penggunaan model pembelajaran inkuiri terbimbing dengan metode eksperimen ini tentunya memiliki kendala. Beberapa diantaranya yakni metode ini memerlukan ketelitian dalam proses belajarnya karena kurangnya ketelitian dapat memberikan hasil yang kurang maksimal serta membutuhkan waktu yang lebih lama karena siswa harus melakukan percobaan dengan teliti dan tidak terburu-buru untuk memperoleh hasil yang benar-benar maksimal. Untuk itu, agar tujuan pembelajaran dapat tercapai dengan maksimal, disini guru perlu memberikan perhatian lebih agar selama kegiatan pembelajaran terutama pada saat melakukan eksperimen/percobaan, siswa tidak ada yang main-main dengan alat dan bahan praktikum, sehingga siswa benar-benar fokus pada kegiatan pembelajaran hari itu dalam melakukan eksperimen.

\section{PENUTUP}

Berdasarkan hasil penelitian, analisis data, serta pembahasan maka dapat disimpulkan bahwa terdapat pengaruh model pembelajaran inkuiri terbimbing dengan metode eksperimen terhadap hasil belajar fisika siswa kelas XI IPA SMAN 2 Mataram tahun pelajaran 2016/2017. Nilai rata-rata tes hasil belajar fisika kelas eksperimen yang menggunakan model pembelajaran inkuiri terbimbing dengan metode eksperimen lebih tinggi dibanding kelas kontrol yang menggunakan model pembelajaran konvensional. Nilai $\mathrm{N}$-gain tertinggi berada pada sub materi sifat elastisitas bahan dan terendah pada sub materi susunan pegas. Hal ini terjadi pada kelas eksperimen dan kelas kontrol. Meskipun demikian, peningkatan tetap lebih tinggi pada kelas eksperimen yang menggunakan model pembelajaran inkuiri terbimbing dengan metode eksperimen.

\section{UCAPAN TERIMA KASIH}

Penulis menyampaikan ucapan terima kasih yang sebanyak-banyaknya kepada semua pihak yang turut serta membantu dalam penelitian ini, pihak sekolah SMAN 2 Mataram serta untuk kedua dosen pembimbing hebat yang selalu sabar dan penuh semangat memberikan masukan dan sarannya, serta untuk teman-teman semua atas dukungan dan motivasinya.

\section{REFERENSI}

[1] Hikmawati, dan Gunada, I.W. 2013. Kajian fisikaSMA. Mataram: FKIP Uniersitas Mataram.

[2] Partono, L.N.R.K. 2014. Pengaruh Model pembelajaran Inkuiri Terbimbing terhadap hasil Belajar Fisika Siswa kelas VIII SMP Negeri 4 Metro Semester Genap Tahun Pelajaran 2013/2014. Jurnal Pendidikan Fisika Universitas Muhammadiyah Metro: 64-72

[3] Usman, M.N. 2013. Menjadi Guru Profesional. Bandung: PT REMAJA ROSDAKARYA.

[4] Trianto. 2010. Mendesain Model Pembelajaran Inovatif-Progresif Konsep, Landasan dan Implementasinya pada Kurikulum Tingkat Satuan Pendidikikan (KTSP). Jakarta: Kencana Prenada Media Group.

[5] Putra, S.R. 2013. Desain Belajar Mengajar Kreatif Berbasis sains. Yogyakarta: Bumi Aksara.

[6] Abidin, Y. 2014. Desain Sistem Pembelajaran dalam Konteks Kurikulum 2013. Bandung: Refika Aditama.

[7] Hartono, R. 2014. Ragam Model Mengajar yang Mudah di Terima Murid. Jogjakarta: Diva Press.

[8] Yulian, P.M., Suratno dan Aisyah, I.N. 2015. "Pengaruh Model Pembelajaran Inkuiri Terbimbing (Giuided Inquiry) dengan Menggunakan Metode Eksperimen terhadap Aktivitas dan Hasil Belajar IPA- 
Biologi Siswa Kelas VIII SMP Negeri 2 Maesan Bondowoso". Jurnal Pancaran, Vol.4, No.2, Mei, Hal 163-172.

[9] Wijayatni, P.I., Mosik, dan Hindarto, N. 2010. "Eksplorasi Kesulitan Belajar Siswa Pada Pokok Bahasan Cahay dan Upaya Peningkatan Hasil Belajar Melaui Pembelajaran Inkuiri Terbimbing". Jurnal Pendidikan Fisika Indonesia, Vol.6, Januari, Hal 1-5.

[10] Isa, A., Wahyudin, dan Sutikno, 2010. Keefektifan pembelajaran Berbantuan Multimedia menggunakan Metode Inkuiri Terbimbing untuk Meningkatkan Minat dan Pemahaman Siswa. Jurnal Pendidikan Fisika Indonesia 6: 58-62.

[11] Sahidu, C. 2013. Pengembangan Program Pembelajaran Fisika (P3F). Mataram: FKIP Press.

[12] Djamarah, S.B., dan Zain, A. 2013. Strategi Belajar Mengajar (Edisi Revisi). Jakarta: Rineka Cipta.

[13] Sagala, S. 2013. Konsep dan Makna Pembelajaran untuk Membantu Memecahkan Problematika Belajar dan Mengajar. Bandung: Alfabeta.

[14] Sudjana, N. 2014. Dasar-dasar Proses Belajar Mengajar. Bandung: Sinar baru Algesindo.

Belajar Mengajar. Bandung: Remaja Rosda Karya.

[16] Setyosari, P. 2013. Metode penelitian dan pengembangan. Jakarta: kencana.

[17] Sugiyono. 2013. Metode Penelitian Pendidikan Pendekatan Kuantitatif, Kualitatif, dan $R \& D$. Bandung: Alfabeta.

[18] Herayanti, L., dan Habibi. 2015.” Model Pembelajaran Berbasis masalah Berbantuan Simulasi Komputer untuk Meningkatkan Keterampilan Berfikir Kritis Calon Guru Fisika”. Jurnal pendidikan Fisika dan Teknologi Universitas Mataram, Vol.1, No.1, januari, hal 61-66.

[19] Justitia, V.S., dan Supardi, Z.A.I. 2015.’Penerapan Model Pembelajaran Inkuiri pada Materi Elastisitas untuk Meningkatkan Hasil Belajar Siswa Kelas
X SMA Negeri 1 Kedamean Gresik". Jural Inovasi Pendidikan Fisika (JPIF), Vol.04 N0. 03, September 2015, Hal 7176.

[20] Sihombing,R. 2015. "Penerapan Pendekatan Inkuiri Terbimbing (Guided Inquiry Approach) pada Pembelajaran Fisika terhadap Hasil Belajar dan Minat Belajar Peserta Didik Kelas X SMA Negeri 3 Jayapura". Jurnal Ilmu Pendidikan Indonesia. Vol 3, No.2, Juni 2015.

\section{Biografi Penulis}

Roni Wahyuni,lahir di Dasan Bagik, Aikmel Lombok Timur 11 Nopember 1993. Penulis telah menyelesaikan pendidikan di SDN 1 AIKMEL tahun 2006, di SMPN 1 AIKMEL tahun 2009 dan di SMAN 1 AIKMEL tahun 2012, kemudian melanjutkan pendidikan S-1 di FKIP Universitas Mataram pada program studi pendidikan fisika, dan lulus pada tahun 2017.

Hikmawati, lahir di Montong Bulok, Lombok Tengah, 31 Desember 1981, menyelesaikan studi S1 Pendidikan Fisika di FKIP Universitas Mataram tahun 2003, sedangkan S2 Pendidikan sains di Universitas Negeri Surabaya tahun 2009. Sejak tahun 2005 menjadi dosen tetap di Program Studi almamaternya dengan fokus kajian riset pada bidang pengembangan perangkat pembelajaran fisika.

Muhammad Taufik, lahir di Medan pada tanggal 23 Maret 1971. Penulis telah menempuh pendidikan jenjang S-1 Pendidikan Fisika di IKIP Medan dan tamat pada tahun 1993, sedangkan S-2 bidang ilmu fisika di UGM Yogyakarta dan tamat pada tahun 1999. Saat ini menjadi tenaga pengajar di program studi pendidikan fisika FKIP UNRAM sejak tahun 1997. 